medRxiv preprint doi: https://doi.org/10.1101/2021.02.06.21251221; this version posted March 31, 2021. The copyright holder for this

preprint (which was not certified by peer review) is the author/funder, who has granted medRxiv a license to display the preprint in

It is made available under a CC-BY-NC-ND 4.0 International license .

\title{
Social predictors of food insecurity during the stay-at-home order due to the COVID-19 pandemic in Peru. Results from a cross-sectional web-based survey
}

Jorge L. Cañari-Casaño ${ }^{1,2}$, Omaira Cochachin-Henostroza ${ }^{3}$, Oliver A. Elorreaga ${ }^{1,2,4}$, Gandy Dolores-Maldonado ${ }^{5}$, Anthony Aquino-Ramírez ${ }^{3}$, Sindy Huaman-Gil ${ }^{5,6}$, Juan P. GiribaldiSierralta $^{5,6}$, Juan Pablo Aparco ${ }^{7,8}$, Daniel A. Antiporta ${ }^{9}$, Mary E. Penny ${ }^{10}$

\section{AFILIATION INSTITUTIONAL}

1. Clima, Latin American Center of Excellence for Climate Change and Health, Universidad Peruana Cayetano Heredia.

2. Emerge, Emerging Diseases and Climate Change Research Unit, School of Public Health and Administration, Universidad Peruana Cayetano Heredia.

3. Grupo de Investigación Nutobes, Universidad Nacional Mayor de San Marcos, Lima, Perú

4. GMINIS Research Group, Pontificia Universidad Católica del Perú

5. Escuela Profesional de Nutrición, Facultad de Medicina, Universidad Nacional Mayor de San Marcos, Lima, Perú

6. Sociedad Científica de Estudiantes de Nutrición, Universidad Nacional Mayor de San Marcos, Lima, Perú

7. Centro Nacional de Alimentación y Nutrición, Instituto Nacional de Salud, Lima, Perú

8. Universidad San Ignacio de Loyola, Carrera de Nutrición y Dietética, Lima, Perú.

9. Department of Epidemiology, Johns Hopkins Bloomberg School of Public Health, Baltimore, MD, USA.

10. Nutrition Research Institute, Lima, Peru. 
medRxiv preprint doi: https://doi.org/10.1101/2021.02.06.21251221; this version posted March 31, 2021. The copyright holder for this preprint (which was not certified by peer review) is the author/funder, who has granted medRxiv a license to display the preprint in It is made available under a CC-BY-NC-ND 4.0 International license .

\section{SUMMARY}

\section{Background}

Stay-at-home orders and social distancing have been implemented as the primary tools to reduce the spread of severe acute respiratory syndrome coronavirus 2 (SARS-CoV-2). However, this approach has indirectly lead to the unemployment of $2 \cdot 3$ million Peruvians, in Lima, Perú alone. As a result, the risk of food insecurity may have increased, especially in low-income families who rely on a daily wage. This study estimates the prevalence of moderate or severe food insecurity (MSFI) and identifies the associated factors that explain this outcome during the stay-at-home order.

\section{Methods}

A cross-sectional web-based survey, with non-probabilistic sampling, was conducted between May 18 and June 30, 2020, during the stay-at-home order in Peru. We used social media advertisements on Facebook to reach 18-59-year-olds living in Peru. MSFI was assessed using the Food Insecurity Experience Scale (FIES). Rasch model methodology requirements were considered, and factors associated with MSFI were selected using stepwise forward selection. A Poisson generalized linear model (Poisson GLM), with log link function, was employed to estimate adjusted prevalence ratios (aPR).

\section{Findings}

This analysis is based on 1846 replies. The prevalence of MSFI was $23 \cdot 2 \%$, and FIES proved to be an acceptable instrument with reliability 0.72 and infit $0 \cdot 8-1 \cdot 3$. People more likely to experience MSFI were those with low income (less than $255 \mathrm{US} \$ /$ month) in the pre-pandemic period (aPR $3 \cdot 77 ; 95 \% \mathrm{CI}, 1 \cdot 98-7 \cdot 16$ ), those whose income was significantly reduced during the pandemic period (aPR 2.27; 95\%CI, 1.55-3.31), and those whose savings ran out in less than 21 days (aPR 1.86; 95\%CI, 1.43-2.42). Likewise, heads of households (aPR 1.20; 95\%CI, 1.00$1 \cdot 44)$ and those with probable SARS-CoV2 cases as relatives (aPR 1.29; 95\%CI, 1.05-1.58) were at an increased risk of MSFI. Additionally, those who perceived losing weight during the pandemic (aPR 1.21; 95\% CI, 1.01-1.45), and increases in processed foods prices (aPR 1.31; 95\% CI, 1.08-1.59), and eating less minimally processed food (aPR 1.82; 95\% CI, 1.48-2.24) were more likely to experience MSFI.

\section{Interpretation}

People most at risk of MSFI were those in a critical economic situation before and during the pandemic. Social protection policies should be reinforced to prevent or mitigate these adverse effects.

\section{Funding}

None. 
medRxiv preprint doi: https://doi.org/10.1101/2021.02.06.21251221; this version posted March 31, 2021. The copyright holder for this preprint (which was not certified by peer review) is the author/funder, who has granted medRxiv a license to display the preprint in

It is made available under a CC-BY-NC-ND 4.0 International license .

\section{INTRODUCTION}

By the end of January 2020, the world had experienced over 100 million SARS-CoV2 cases, of whom approximately 2.3 million have died. ${ }^{(1)}$ Peru has had around 1 million cases and more than 41,000 have died from SARS-CoV2.(2) Moreover, Peru is one of the countries with the highest SARS-CoV2 mortality rate in the world.$^{(3)}$ After declaring a global health emergency, ${ }^{(4)}$ the World Health Organization (WHO) recommended social distancing and closing public and private services, among other measures to contain the spread of SARS-CoV2.

Two principal measures adopted by many countries were stay-at-home orders and border closures (i.e., national lockdowns). In Peru, these were implemented from March 16 to June 30, 2020. People were only allowed to go out for essential activities, for instance to buy food and medicine. However, due to the precarious labour market in Peru, where informal labour constitutes $50 \%$ of all labour, ${ }^{(5)}$ and pre-pandemic poverty the purchasing power of Peruvian families was severely affected by the lockdown. The Peruvian government tried to help this vulnerable population by giving social aid (i.e., financial stimulus to families, early withdrawal from the private retirement pension, and food donations) to face the stay-at-home orders' side effects. It has been suggested that this was not enough due to inefficient distribution and the already critical situation exacerbated by COVID-19 pandemic. ${ }^{(6)}$

stay-at-home orders could affect food insecurity due to the resulting economic crisis, massive loss of jobs, high food prices, and growing demand for medical care. ${ }^{(7)}$ These results may generate short- and medium-term adverse health effects. ${ }^{(7)}$ Recent research on the short-term impacts of stay-at-home orders supports this idea. One of the first studies in Peru reported a considerable income reduction after stay-at-home orders in $37 \%$ of the participants, ${ }^{(8)}$ and over 2.3 million lost jobs in Lima alone ${ }^{(9)}$ Similar occurrences have been reported outside Peru. ${ }^{(11-10)}$ Furthermore, higher food prices, changes in diets, increased depression, anxiety and physical violence against women have all been associated with stay-at-home orders. ${ }^{(11,12,13)}$

Recent studies have also reported an increase in food insecurity after implementation of stay-athome orders, ${ }^{(14-16)}$ which worsens as the crisis intensifies. ${ }^{(11)}$ These results are alarming, especially considering that the World Food Program estimated the number of people experiencing food insecurity will increase to 265 million by the end of $2020,{ }^{(17)}$ accompanied by potential negative effects on health and household relations. ${ }^{(7)}$

While MSFI was estimated at $29.9 \%$ between 2014-2016 in Peru, ${ }^{(18)}$ little data exist regarding how stay-at-orders have affected MSFI. The present study aimed to estimate the prevalence of MSFI and determine the factors associated with MSFI in our study population. 


\section{Research in context \\ Evidence before this study}

Stay-at-home orders established to stop the spread of the COVID-19 pandemic have caused profound adverse effects in low- and middle-income countries such as Peru, specifically in economically vulnerable populations, who are most at risk for food insecurity. We searched PubMed servers up to Jan 20, 2020, for peer-reviewed articles published using the terms "(food insecurity OR food security) AND (COVID-19 OR SARS-CoV2) OR (stay-at-home order OR Quarantine OR lockdown)", without data or language restrictions. Our search found few studies that have examined the direct or indirect impact of stay-at-home orders on moderate-severe food insecurity (MSFI). However, the available evidence is scarce in low- and middle-income settings, especially Latin American countries such as Peru.

\section{Added value of this study}

To our knowledge, this study provides one of the first pieces of evidence about the prevalence of MSFI, measured using the Food Insecurity Experience Scale (FIES), and its associated factors during the stay-at-home order in Peru. Our findings agree with the growing scientific literature reporting that those most at risk of MSFI occupy tenuous economic positions before and during the pandemic.

\section{Implications of all the available evidence}

It is urgent to implement social protection policies that aim to strengthen real-time systems focusing on identifying and providing social assistance to vulnerable populations most at risk of MSFI. These systems should consider that non-poor households can quickly descend into poverty due to the inability of day laborers to work during stay-at-home orders. It is also essential to identify appropriate social aid strategies (money transfers, food donations, communal pots of food, etc.) according to the vulnerable population's characteristics and state of the pandemic. These recommendations may mitigate the adverse effects of stay-at-home orders on food MSFI.

\section{METHODS}

\section{Study design and participants}

In this cross-sectional study an online survey administered through the Qualtrics platform was used to estimate the prevalence of and factors associated with MSFI. The survey was administered to Peruvian adults, 18 to 59 years old who had internet and social media (Facebook) access by mobile devices or computers.

\section{Procedures}

The survey was accessible between May 18 and June 30 during the stay-at-home order. The dissemination of this study was done by: (1) paid advertisements from the "Colegio de Nutricionistas del Perú" official social media site; (2) social media posts by public and private universities and Peruvian research centres, and (3) by dissemination of the online survey link by participants through their personal social media profile or through their WhatsApp groups and contacts. 
medRxiv preprint doi: https://doi.org/10.1101/2021.02.06.21251221; this version posted March 31, 2021. The copyright holder for this preprint (which was not certified by peer review) is the author/funder, who has granted medRxiv a license to display the preprint in

It is made available under a CC-BY-NC-ND 4.0 International license.

Participants who clicked on the link were redirected to a Qualtrics survey platform to read more about the study and consent before starting the survey. The survey could be answered more than once, and if this happened, participants had to mention why they were repeating the survey. Participants who completed the study were invited to download educational material on "Healthy Eating" and asked to share the survey link through their social media and WhatsApp contacts.

The online survey collected sociodemographic information (i.e., place of residence, sex, age, marital status, nationality, educational level, employment status, whether they suffered from a chronic disease or disability, SARS-CoV2 symptoms or any relative that tested positive for SARS-CoV2 in participant environment); FIES; household information (i.e., number of household members, average monthly income, economic condition during stay-at-home order, emergency savings, government financial support, water connection and drainage); perception about food prices (i.e., prices relative to pre-pandemic period: "lower price", "same price", "higher price", "do not know/prefer not to answer"); perception about food consumption (i.e., "eat less", "eat the same", "eat more", "do not eat/prefer not to answer"); perception about places to buy and waiting time, and perception about body weight status before and during the pandemic using body shape images were included in the questionnaire. To validate the survey questionnaire, a pilot study was conducted by phone call to 23 people of different age groups.

\section{Food Insecurity Measurement}

We used the Food Insecurity Experience Scale (FIES) at the individual level to determine the prevalence of MSFI. The FIES is an eight-item questionnaire with dichotomous responses (i.e., Yes or No) about experiences with food insecurity at the household or individual level.

The FIES was developed by Food and Agriculture Organization's (FAO) Voices of the Hungry $(\mathrm{VoH})$ project and was validated in 151 countries with Gallup World Poll (GWP) data in 2014. . $^{(19-}$ ${ }^{21)}$ Several studies have used FIES to determine food insecurity in different fields and context. ${ }^{(22-}$ 28)

We adapted the FIES questionnaire to the Peruvian context taking into consideration a study by Vargas and Penny, ${ }^{(29)}$ and a pilot study $(\mathrm{n}=23)$ where content and understanding were evaluated. Minor modifications were done to the formulation of the questions and the whole questionnaire was translated into Spanish (Table 1).

To analyze and determine MSFI, we only considered people who responded positively (value: 1) or negatively (value: 0 ) to all questions on the FIES. Since the FIES scale fulfilled all Rasch model assumptions (reliability and infit), a raw score was obtained (i.e., sum of affirmative responses). Individuals with raw scores between 4-8 were classified as MSFI and those with scores of 0-3 were classified as not having MSFI. ${ }^{(30)}$ Similar cut off points were used to determine MSFI in other studies. $^{(22,26,31,32)}$

Table 1: Food Insecurity Experiences Scale (FIES) ${ }^{1}$

\begin{tabular}{|l|l|l|l|}
\hline Order & Questions & Items & Possible answers \\
\hline Q1 & $\begin{array}{l}\text { During the last month of quarantine, was there a time when, } \\
\text { because of lack of money or other resources, you were worried } \\
\text { you would not have enough food to eat? }\end{array}$ & WORRIED & $\begin{array}{l}1=\text { Yes } \\
2=\text { No } \\
3=\text { Don't Know } \\
4=\text { Prefer not to answer }\end{array}$ \\
\hline Q2 & $\begin{array}{l}\text { During the last month of quarantine, was there a time when, } \\
\text { because of lack of money or other resources, you could not eat } \\
\text { healthy and nutritious food? For example: meat, fish, fruits, or } \\
\text { vegetables. }\end{array}$ & HEALTHY & $\begin{array}{l}1=\text { Yes } \\
2=\text { No } \\
3=\text { Don't Know } \\
\text { 4=Prefer not to answer }\end{array}$ \\
\hline
\end{tabular}


medRxiv preprint doi: https://doi.org/10.1101/2021.02.06.21251221; this version posted March 31, 2021. The copyright holder for this preprint (which was not certified by peer review) is the author/funder, who has granted medRxiv a license to display the preprint in It is made available under a perpetuity. perpetuity.

\begin{tabular}{|c|c|c|c|}
\hline Q3 & $\begin{array}{l}\text { During the last month of quarantine, was there a time when, } \\
\text { because of lack of money or other resources, you had to eat only } \\
\text { a few kinds of foods? }\end{array}$ & FEWFOODS & $\begin{array}{l}1=\text { Yes } \\
2=\text { No } \\
3=\text { Don't Know } \\
4=\text { Prefer not to answer }\end{array}$ \\
\hline Q4 & $\begin{array}{l}\text { During the last month of quarantine, was there a time when, } \\
\text { because of lack of money or other resources, you had to reduce } \\
\text { the number of meals per day because you did not have enough } \\
\text { food? For example, skip breakfast, lunch, or dinner? }\end{array}$ & SKIPPED & $\begin{array}{l}1=\text { Yes } \\
2=\text { No } \\
3=\text { Don't Know } \\
4=\text { Prefer not to answer }\end{array}$ \\
\hline Q5 & $\begin{array}{l}\text { During the last month of quarantine, was there a time when, } \\
\text { because of lack of money or other resources, you had to eat less } \\
\text { than you thought you should eat? }\end{array}$ & ATELESS & $\begin{array}{l}1=\text { Yes } \\
2=\text { No } \\
3=\text { Don't Know } \\
4=\text { Prefer not to answer }\end{array}$ \\
\hline Q6 & $\begin{array}{l}\text { During the last month of quarantine, was there a time when, } \\
\text { because of lack of money or other resources, your food ran out in } \\
\text { your household? }\end{array}$ & RANOUT & $\begin{array}{l}1=\text { Yes } \\
2=\text { No } \\
3=\text { Don't Know } \\
4=\text { Prefer not to answer }\end{array}$ \\
\hline Q7 & $\begin{array}{l}\text { During the last month of quarantine, was there a time when, } \\
\text { because of lack of money or other resources, you went to sleep } \\
\text { hungry because there was not enough food? }\end{array}$ & HUNGRY & $\begin{array}{l}1=\text { Yes } \\
2=\text { No } \\
3=\text { Don't Know } \\
4=\text { Prefer not to answer }\end{array}$ \\
\hline Q8 & $\begin{array}{l}\text { During the last month of quarantine, was there a time when, } \\
\text { because of lack of money or other resources, you went without } \\
\text { eating for a whole day? }\end{array}$ & WHLDAY & $\begin{array}{l}1=\text { Yes } \\
2=\text { No } \\
3=\text { Don't Know } \\
4=\text { Prefer not to answer }\end{array}$ \\
\hline
\end{tabular}

${ }^{1}$ The Spanish version of the FIES is provided in the supplementary material.

\section{Covariates}

Sociodemographic variables including age, sex, place of residence, educational level, if respondent was a head of household, and number of household members were considered. Household income level before and during the pandemic were related to an individual's financial status and use and duration of savings during the stay-at-home order. Variables related to social assistance included support given by the government or any institution. Variables used to understand changes since the emergency began, included changes in location where food was bought and principal food groups consumed (i.e., healthy or minimally processed food, culinary ingredients, processed food, and ultra-processed foods). Body weight perceptions before and during the pandemic were evaluated using the Stunkard scale. ${ }^{(33)}$ Finally, variables related to COVID-19 pandemic were also considered; specifically, participants reporting a SARS-CoV2 diagnosis, loss of smell/taste, or whose household members had or had had SARS-CoV2.

\section{Data Analysis}

Rash model assumptions for the FIES scale were evaluated using the RM.weight package in R statistical software, ${ }^{(21,34)}$ where performance of an eight-item questionnaire was assessed utilizing infit statistic and the ability to distinguish different levels of food insecurity in participants was evaluated with the reliability of FIES scale. After verifying the fulfilment of the FIES scale's assumptions, food insecurity was determined using the raw score (the sum of affirmative responses). Descriptive analysis of categorical variables and bivariate analysis between MSFI and other predictor variables were performed by proportions and chi-square test, respectively. Factors associated with the predictor variables and MSFI were determined using forward stepwise selection, starting with the most significant predictor variable. We used Poisson generalized linear models (Poisson GLMs) with log link function, to estimate adjusted prevalence ratios (aPR) fitted at the departmental level. Data analysis was performed using Stata 15.0 (Stata Corp., College Station, Texas - United States) and software program R studio (Version 4.0.4; R Foundation for Statistical Computing, Vienna, Austria). 
medRxiv preprint doi: https://doi.org/10.1101/2021.02.06.21251221; this version posted March 31, 2021. The copyright holder for this preprint (which was not certified by peer review) is the author/funder, who has granted medRxiv a license to display the preprint in It is made available under a CC-BY-NC-ND 4.0 International license .

\section{Ethical Issues}

The study was approved by the human ethics committee of "Instituto de Investigación Nutricional" (CIEI-IIN), Lima - Peru, No 394-2020/CIEI-IIN.

\section{RESULTS}

A total of 2643 people answered the study's informed consent, and 116 declined to participate in the study. Fifty-two participants were excluded because we could not determine if they had taken the survey more than once or they retook the survey for an inadequate reason and 629 participants because they did not answer all the questions on the FIES scale. The final sample considered for the analysis was 1846 participants (Figure 1).

\section{Figure 1: Flow diagram}

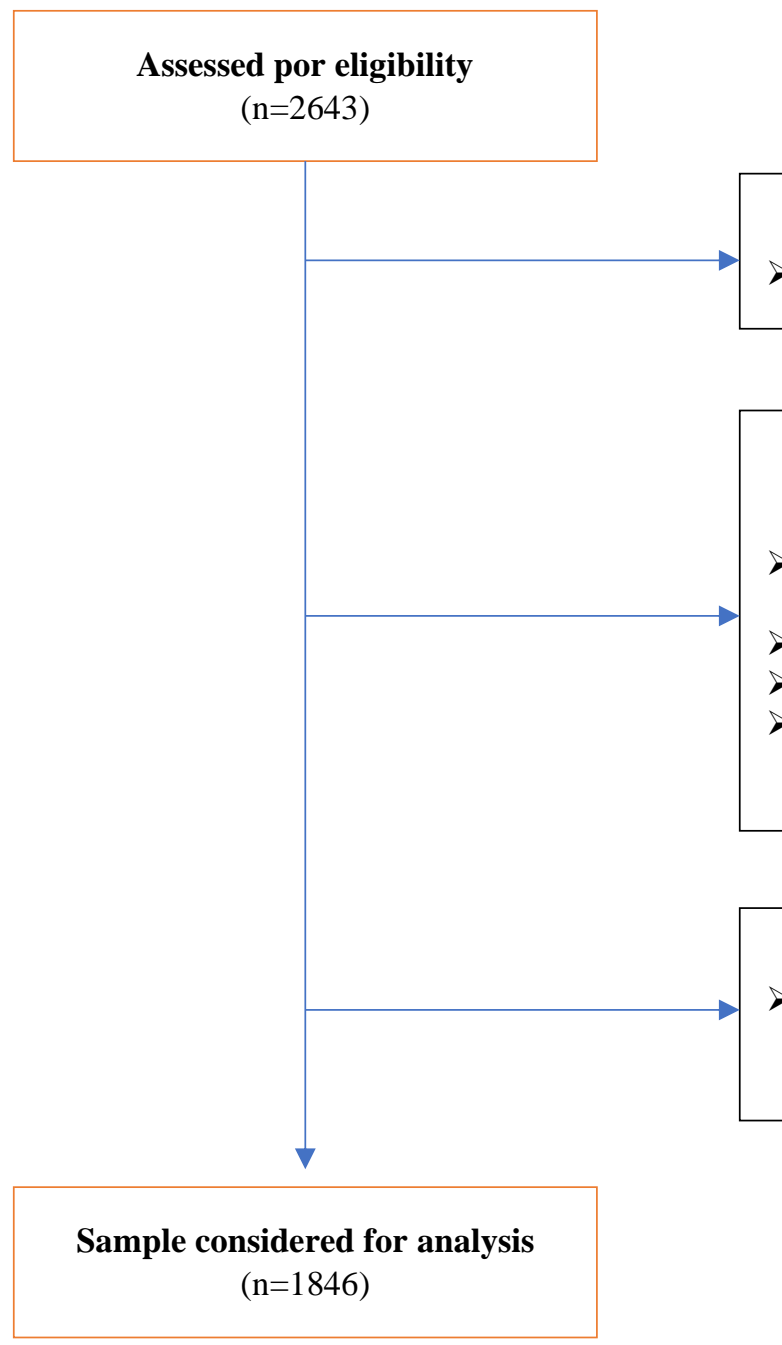

Excluded from the analysis 1: $\mathbf{n = 1 1 6}$

Refused informed consent $(n=116)$

\section{Excluded from the analysis 2: $\mathbf{n = 5 2}$}

Did not respond if they were filling out the survey for the first time $(n=26)$

Entered the survey again to correct their answers $(n=5)$

Entered only to see their answers again $(n=7)$

Did not answer why they were retaking the survey $(n=14)$

Did not answer negatively or affirmatively way all the questions of the FIES questionnaire $(n=629)$

Table 2 shows the infit statistic and the Rasch model parameters. Infit values were acceptable, and Rasch model reliability in the FIES scale was 0.72 (data not shown in the table) which was also acceptable (greater than $0 \cdot 7$ ).

Table 2: Evaluation of the assumptions of the Rash model of the FIES scale. 
medRxiv preprint doi: https://doi.org/10.1101/2021.02.06.21251221; this version posted March 31, 2021. The copyright holder for this preprint (which was not certified by peer review) is the author/funder, who has granted medRxiv a license to display the preprint in It is made available under a CC-BY-NC-ND 4.0 International license .

\begin{tabular}{|c|c|c|c|c|}
\hline Item & Item_sev.** & St.err. ${ }^{\phi}$ & Infit $^{¥}$ & Outfit \\
\hline WORRIED & $-2 \cdot 37100181$ & $0 \cdot 0804195$ & $1 \cdot 2714576$ & $2 \cdot 2715038$ \\
\hline FEWFOOD & $-1 \cdot 99919744$ & 0.0785325 & $0 \cdot 8542389$ & 0.7456257 \\
\hline HEALTHY & -0.72783574 & 0.0818627 & $1 \cdot 0229524$ & 0.9484038 \\
\hline ATELESS & $-0 \cdot 8382067$ & $0 \cdot 08112009$ & $0 \cdot 8300268$ & 0.7194007 \\
\hline SKIPPED & 0.02735437 & 0.0891645 & 0.9363935 & $0 \cdot 8611874$ \\
\hline RUNOUT & 0.69432414 & $0 \cdot 09915824$ & $1 \cdot 1374597$ & $1 \cdot 2012408$ \\
\hline HUNGRY & $1 \cdot 31138247$ & $0 \cdot 1125294$ & $0 \cdot 8408805$ & 0.7309963 \\
\hline WHLDAY & $3 \cdot 90325585$ & $0 \cdot 25963247$ & $1 \cdot 0598114$ & 0.7132612 \\
\hline
\end{tabular}

*Item_sev: Item severity. ${ }^{\phi}$ St.err: Standard error. ${ }^{\sharp}$ Infit: Infit statistic. Acceptable values are in the range of $0 \cdot 7$ - $0 \cdot 13$.

Most of the participants were women (74.9\%) with a technical or university education $(85.3 \%)$. About a third were heads of household (34.2\%) and lived-in provinces other than Metropolitan Lima (32.2\%). Regarding economic factors, a low proportion of people $(12.4 \%)$ received less than the minimum wage in Peru (less than 255 US\$/month) before the pandemic and only $23.4 \%$ continued receiving income during the stay-at-home orders. On the other hand, over half of participants $(56.7 \%$ ) had emergency savings left to address the pandemic, while $16 \%$ and $9.5 \%$ of people ran out of savings in 22-35 days and less than 21 days since the start of the stay-at-home order, respectively.

As for factors related explicitly to the stay-at-home order, we found $17 \%$ of people had relatives with probable cases of SARS-CoV2, 30\% stayed at home without working but had worked in the pre-pandemic period, $38.1 \%$ were working during the stay at home period, and $26.8 \%$ were not working before or during the stay at home order. $71.6 \%$ reported that the process to buy food took more time than before, and only $23.4 \%$ mentioned they received some support (include the government and private support) during the COVID-19 pandemic. In relation to body weight perceptions, $24.9 \%$ people perceived losing weight, $32.1 \%$ maintained their weight, and $30.7 \%$ gained weight. Regarding natural or minimally processed food consumption, $30 \%$ of participants mentioned that they ate less of this food group, and 39\% ate more. It was found that $23.3 \%$ of participants experienced MSFI (Table 3).

Table 3. General characteristics of the population studied.

\begin{tabular}{ll}
\hline Characteristics & $\begin{array}{l}\mathbf{N} \\
(\mathbf{n = 1 8 4 6})\end{array}$ \\
\hline Sociodemographic factors & \\
$\quad$ Sex & \\
$\quad$ Female & $1383(74 \cdot 9 \%)$ \\
Male & $451(24 \cdot 4 \%)$ \\
Missing/prefer not to answer & $12(0 \cdot 7 \%)$ \\
Age & \\
$18-25$ & $723(39 \cdot 2 \%)$ \\
$26-35$ & $516(30 \cdot 0 \%)$ \\
$36-59$ & $607(32 \cdot 9 \%)$ \\
Level of education & \\
Higher university education & $1353(73 \cdot 3 \%)$ \\
Higher technical education & $222(12 \cdot 0 \%)$ \\
Up to secondary education & $250(13 \cdot 5 \%)$
\end{tabular}


medRxiv preprint doi: https://doi.org/10.1101/2021.02.06.21251221; this version posted March 31, 2021. The copyright holder for this preprint (which was not certified by peer review) is the author/funder, who has granted medRxiv a license to display the preprint in It is made available under a CC-BY-NC-ND 4.0 International license .

Missing/prefer not to answer

Head of household

No

Yes

Missing/prefer not to answer

Place of residence

Province of Metropolitan Lima

Other provinces or departments

Missing/prefer not to answer
$21(1 \cdot 1 \%)$

$1167(63 \cdot 2 \%)$

$631(34 \cdot 2 \%)$

$48(2 \cdot 6 \%)$

$1249(67 \cdot 7 \%)$

$594(32.2 \%)$

$3(0.2 \%)$

$181(9 \cdot 8 \%)$

$452(24 \cdot 5 \%)$

$644(34.9 \%)$

$228(12.4 \%)$

$341(18 \cdot 5 \%)$

$432(23 \cdot 4 \%)$

$542(29.4 \%)$

$748(40 \cdot 5 \%)$

$124(6 \cdot 7 \%)$

$1047(56 \cdot 7 \%)$

$296(16 \cdot 0 \%)$

$175(9.5 \%)$

$328(17 \cdot 8 \%)$

\section{Factors related to the COVID-19 pandemic}

People with relatives with probable cases of SARS-CoV2

Without probable cases of SARS-CoV2

$1529(82 \cdot 8 \%)$

With probable cases of SARS-CoV2

$314(17 \cdot 0 \%)$

Missing/prefer not to answer

The main situation during the COVID-19 pandemic

Staying at home without working

Usually does not work

Working in this period

$704(38 \cdot 1 \%)$

Missing/prefer not to answer

$93(5 \cdot 0 \%)$

Waiting time to purchase of most food

It is slower, takes longer to do the shopping

$1321(71 \cdot 6 \%)$

It is the same as the pre-pandemic time

It is faster. It takes less time

Missing/prefer not to answer

Change in the usual place of purchase of most food 
medRxiv preprint doi: https://doi.org/10.1101/2021.02.06.21251221; this version posted March 31, 2021. The copyright holder for this preprint (which was not certified by peer review) is the author/funder, who has granted medRxiv a license to display the preprint in It is made available under a CC-BY-NC-ND 4.0 International license .

Changed the place of purchase

$875(47 \cdot 4 \%)$

Did not change the place of purchase

$736(39.9 \%)$

Missing/prefer not to answer

$235(12.7 \%)$

Perception of food price of processed foods during COVID-19 pandemic

Lowered or maintained

Price increased

Missing/prefer not to answer

\section{Social support in the COVID-19 pandemic}

Received some support during the COVID-19 pandemic
Yes
$432(23.4 \%)$
No
Missing/prefer not to answer
$88(4.8 \%)$

\section{Perception of body condition}

Perception of weight loss during the COVID-19 pandemic
Maintained or gained weight
$1159(62 \cdot 8 \%)$
Lost weight
$459(24.9 \%)$
Missing/prefer not to answer

\section{Food patterns and food insecurity}

Perception of consumption of minimally processed foods during the COVID-19 pandemic
Ate the same or more
Ate less
Missing/prefer not to answer
Moderate-Severe Food insecurity (MSFI)
No
Yes

Table 4. Bivariate analysis of potential factors associated with moderate or severe food insecurity.

\begin{tabular}{|c|c|c|c|}
\hline \multirow[b]{2}{*}{ Variables } & \multicolumn{2}{|c|}{ Moderate or Severe Food Insecurity } & \multirow[b]{2}{*}{$\mathbf{P}^{*}$} \\
\hline & $\begin{array}{l}\text { No }(\text { total=1418) } \\
\mathrm{n}(\%)\end{array}$ & $\begin{array}{ll}\text { Yes } & (\text { total=428) } \\
\text { n }(\%)\end{array}$ & \\
\hline \multicolumn{4}{|l|}{ Sociodemographic factors } \\
\hline Head of household & & & $0 \cdot 018$ \\
\hline No & $914(78 \cdot 3 \%)$ & $253(21 \cdot 7 \%)$ & \\
\hline Yes & $463(73 \cdot 4 \%)$ & $168(26 \cdot 6 \%)$ & \\
\hline \multicolumn{4}{|l|}{ Economic factors } \\
\hline Household income pre-pandemic period (US\$/month) & & & $<0.001$ \\
\hline More than 1788 & $168(92 \cdot 8 \%)$ & $13(7 \cdot 2 \%)$ & \\
\hline $767-1787$ & $403(89 \cdot 2 \%)$ & $49(10 \cdot 8 \%)$ & \\
\hline $256-766$ & $461(71 \cdot 6 \%)$ & $183(28 \cdot 4 \%)$ & \\
\hline Less than 255 & $113(49 \cdot 6 \%)$ & $115(50 \cdot 4 \%)$ & \\
\hline
\end{tabular}


medRxiv preprint doi: https://doi.org/10.1101/2021.02.06.21251221; this version posted March 31, 2021. The copyright holder for this preprint (which was not certified by peer review) is the author/funder, who has granted medRxiv a license to display the preprint in It is made available under a CC-BY-NC-ND 4.0 International license .

Household income during COVID-19 pandemic

Still receiving income

$395(91.4 \%)$

$37(8 \cdot 6 \%)$

Income decreased slightly

$457(84 \cdot 3 \%)$

$85(15 \cdot 7 \%)$

Income decreased considerably or ceased

$466(62 \cdot 3 \%)$

$282(37 \cdot 7 \%)$

Duration of savings to address the COVID-19 pandemic (grouped in days)
Still have savings
It ran out between 22 to 35 days
It ran out in less than 21 days

$\begin{array}{ll}908(86 \cdot 7 \%) & 139(13 \cdot 3 \%) \\ 161(54 \cdot 4 \%) & 135(45 \cdot 6 \%) \\ 85(48 \cdot 6 \%) & 90(51.4 \%)\end{array}$

$<0 \cdot 001$

Factors related to the COVID-19 pandemic

People with relatives with probable cases of SARS-CoV2

Without probable cases of SARS-CoV2

With probable cases of SARS-CoV2

$1200(78 \cdot 5 \%) \quad 329(21 \cdot 5 \%)$

$216(68.6 \%) \quad 98(31 \cdot 2 \%)$

$<0 \cdot 001$

The main situation during the Covid-19 pandemic

Staying at home without working

Usually does not work

$385(69.4 \%) \quad 170(30.6 \%)$

$384(77.7 \%) \quad 110(22.3 \%)$

Working in this period

$581(82.5 \%)$

$123(17 \cdot 5 \%)$

Waiting time to purchase of most food

It is slower, takes longer to do the shopping

It is the same as the pre-pandemic time

It is faster. It takes less time

$1000(75.7 \%) \quad 321(24.3 \%)$

$173(82.4 \%) \quad 37(17.6 \%)$

$67(85.9 \%) \quad 11(14.1 \%)$

Change in the usual place of purchase of most food

Changed the place of purchase

$656(75 \cdot 0 \%)$

$0 \cdot 013$

Did not change the place of purchase

$590(80 \cdot 2 \%)$

$219(25 \cdot 0 \%)$

Perception of food price of processed foods during the COVID-

19 pandemic

Lowered or maintained

$465(82 \cdot 5 \%)$

$99(17 \cdot 6 \%)$

$<0 \cdot 001$

Price increased

$757(73 \cdot 8 \%)$

$269(26 \cdot 2 \%)$

\section{Social support in the COVID-19 pandemic}

Received some support during the COVID-19 pandemic

Yes

No

$\begin{array}{ll}284(65 \cdot 7 \%) & 148(34 \cdot 3 \%) \\ 1066(80 \cdot 4 \%) & 260(19 \cdot 6 \%)\end{array}$

\section{Perception of body condition}

Perception of weight loss during the COVID-19 pandemic

Maintained or gained weight

$29(80 \cdot 2 \%) \quad 230(19 \cdot 8 \%)$

Lost weight

$318(69 \cdot 3 \%)$

$141(30 \cdot 7 \%)$

$0 \cdot 017$

$<0 \cdot 001$

Food patterns and food insecurity

Perception of consumption of minimally processed foods during the COVID-19 pandemic

\begin{tabular}{lll} 
Ate the same or more & $944(86 \cdot 7 \%)$ & $145(13 \cdot 3 \%)$ \\
Ate less & $323(58 \cdot 4 \%)$ & $230(41.6 \%)$ \\
\hline
\end{tabular}

* Chi-square test.

In bivariate analysis between MSFI and principal predictor variables, most were found to be significant, except for participant sex and age (table 4). The factors associated with MSFI are shown in Table 5. Among sociodemographic factors, participants who were heads of households had a prevalence of MSFI up to 1.2 times higher compared to participants who were not (aPR 
medRxiv preprint doi: https://doi.org/10.1101/2021.02.06.21251221; this version posted March 31, 2021. The copyright holder for this preprint (which was not certified by peer review) is the author/funder, who has granted medRxiv a license to display the preprint in It is made available under a CC-BY-NC-ND 4.0 International license .

1.20, CI95\%: 1.00-1.44). In relation to economic factors, people whose households had an average monthly income of $<255$ US\$/month and between 256 to 766 US\$/month in the prepandemic period had a prevalence of MSFI up to 3.8 (aPR 3.77 CI95\%: 1.98-7.16) and 2.8 (aPR $2 \cdot 80$ CI95\%: 1.50-5.23) times higher, respectively compared to households with an average monthly income of more than 1788 US\$/month. People whose savings to address the emergency ran out in between 22 to 35 days and less than 21 days since the start of the stay-at-home order, had a prevalence of MSFI up to 1.84 (aPR 1.84, CI95\%: 1.46-2.31) and 1.86 (aPR 1.86, CI95\%: 1.43-2.42) times higher, respectively, compared to people with savings left to address the emergency.

On the other hand, participants with relatives who were probable cases of SARS-CoV2 had a prevalence of MSFI up to 1.29 (aPR 1.29, CI95\%: 1.05-1.58) times higher relative to those who did not. Participants who reported a loss of weight during the pandemic period had a prevalence of MSFI 1.21 (aPR 1.21, CI95\%: 1.01-1.45) times higher than those who maintained or gained weight. Lastly, participants who reported consuming less natural or minimally processed food had a prevalence of MSFI 1.82 (aPR 1.82, CI95\%: 1.48-2.24) times higher than those who ate the same or more of that food group. Participants who reported increases in processed foods prices had a prevalence of MSFI 1.31 (aPR 1.31; 95\%CI, 1.08-1.59) times higher than those who reported that prices were maintained or decreased.

Table 5. Prevalence ratios of factors associated with moderate-severe food insecurity. Peru

\begin{tabular}{|c|c|c|c|}
\hline \multirow{2}{*}{ Variables } & \multicolumn{3}{|c|}{ Multivariate regression analysis. } \\
\hline & aPR* & $(95 \% \mathrm{CI})$ & $\mathbf{p}$ \\
\hline \multicolumn{4}{|c|}{ Sociodemographic factors } \\
\hline \multicolumn{4}{|c|}{ Head of household } \\
\hline No & Ref. & & \\
\hline Yes & $1 \cdot 20$ & $(1 \cdot 00-1 \cdot 44)$ & 0.047 \\
\hline
\end{tabular}

\section{Economic factors}

Household income pre-pandemic period (US\$/month)

More than 1788

Ref.

767-1787

$1 \cdot 47$

$(0 \cdot 75-2 \cdot 86)$

$0 \cdot 259$

256-766

$2 \cdot 80$

Less than 255

$3 \cdot 77$

$(1 \cdot 50-5 \cdot 23)$

$0 \cdot 001$

Less than 255

Household income during COVID-19 pandemic

Still receiving income

Ref.

Income decreased slightly

Income decreased considerably or ceased

$\begin{array}{lll}1.54 & (1.02-2.31) & 0.039 \\ 2.27 & (1.55-3.31) & <0.001\end{array}$

Duration of savings to address the COVID-19 pandemic (grouped in days)

Still have savings

Ref.

It ran out between 22 to 35 days

$1 \cdot 84$

$(1 \cdot 98-7 \cdot 16)$

$<0 \cdot 001$

It ran out in less than 21 days

1.86

$(1 \cdot 46-2 \cdot 31)$

$<0 \cdot 001$

$(1.43-2 \cdot 42)$

$<0 \cdot 001$

\section{Factors related to the COVID-19 pandemic}

People with relatives with probable cases of SARS-CoV2

Without probable cases of SARS-CoV2

Ref. 
medRxiv preprint doi: https://doi.org/10.1101/2021.02.06.21251221; this version posted March 31, 2021. The copyright holder for this preprint (which was not certified by peer review) is the author/funder, who has granted medRxiv a license to display the preprint in It is made available under a CC-BY-NC-ND 4.0 International license .

With probable cases of SARS-CoV2

Perception of food price of processed foods during COVID-19 pandemic

Lowered or maintained

Ref.

Price increased

\section{Perception of body condition}

Perception of weight loss during the COVID-19 pandemic

Maintained or gained weight

Ref.

Lost weight

Food patterns and food insecurity

Perception of consumption of minimally processed foods during the COVID-19 pandemic

Ate the same or more

Ref.

Ate less

$1 \cdot 82$

$(1.48-2 \cdot 24)$

$<0 \cdot 001$

aPR: Prevalence ratios adjusted. Multivariate regression analysis fitting by department level considering the constitutional province of Callao as a department.

\section{DISCUSSION}

The present study found a prevalence of MSFI of $23 \cdot 2 \%$. Factors associated with it were having an income below the minimum living wage in the pre-pandemic period, having experienced a substantial reduction in income during the pandemic, ran out of savings in the first 21 days of the pandemic period, being a head of household, having relatives who were probable cases of SARSCoV2, perceiving weight loss during pandemic period, reporting that they ate less natural or minimally processed food, and having perceived an increase in prices of processed foods.

In Peru in 2014, the reported prevalence of MSFI was $29.9 \%{ }^{(35)}$ however, our study found a prevalence of MSFI of 23.2\% in the first 30-45 days of stay-at-home order. Although these results are not comparable with MSFI initial values, the prevalence of MSFI in this study may be underestimated because of some particular characteristics of the population analysed. For example, $73.3 \%$ had a university education, only $12.4 \%$ reported having monthly income less than 255 US $\$$ /month before the pandemic, and participants required internet access and a social network account to access the survey, attributes that low-income people generally do not have and they are precisely the population most at risk of suffering food insecurity. ${ }^{(22,26)}$ Other studies that have evaluated Food Insecurity in the context of the COVID-19 pandemic using FIES have reported higher MSFI prevalence. In Jordan, the prevalence of MSFI was 59.2\%, ${ }^{(36)}$ in Kenya and Uganda MSFI increased from $50 \%$ to $88 \%$ and from $43 \%$ to $87 \%$, from before to during the pandemic, respectively. ${ }^{(15)}$ Our study measures individual MSFI; however, there is already evidence of the effect stay-at-home order on household MSFI. In Mexico, it was reported that the prevalence of household MSFI increased from $24.2 \%$ in 2018 to $30.2 \%$ in June $2020 .{ }^{(31)}$ Vermont also reported is an increase of MSFI from $18.3 \%$ pre-pandemic to $24.4 \%$ during the pandemic. ${ }^{(14)}$ In rural Bangladesh the prevalence of MSFI increased from $8.3 \%$ pre-pandemic to $51.8 \%$ during the pandemic. ${ }^{(11)}$

Our study is one of the first investigations into MSFI during the stay-at-home order due to COVID-19 pandemic in Peru. We found that up to $40.5 \%$ of participants experienced a considerable reduction in their income, similar results were reported by the Young Lives study in Peru with $37 \%$ of households affected by a salary cut or suspension without payment. ${ }^{(8)}$ These high percentages of income losses could be related to the fact that in Peru, 50\% of income came 
medRxiv preprint doi: https://doi.org/10.1101/2021.02.06.21251221; this version posted March 31, 2021. The copyright holder for this preprint (which was not certified by peer review) is the author/funder, who has granted medRxiv a license to display the preprint in

It is made available under a CC-BY-NC-ND 4.0 International license .

from informal employment in the pre-pandemic period. ${ }^{(5)}$ This could explain our results, i.e., those who had lower income (compared to high-income people) before the pandemic, had less capacity to save money to face emergency situations, and had substantial income reduction during the pandemic, are shown to be more likely to have MSFI. These findings are consistent with other studies, for example, in Jordan it was reported that people who had a monthly income per capita below the poverty line were more likely to have moderate (OR: $5 \cdot 33$; 95\% CI: 4.44-6.40) and severe food insecurity and severe food insecurity (OR: 6·87; 95\% CI: 5·542-8.512). ${ }^{(36)}$ Similarly, other studies that explored determinants of food insecurity during the COVID pandemic reported a higher risk of MSFI in low-income people,${ }^{(37)}$ people who lost their job, ${ }^{(14,38)}$ or people with substantial income loss. ${ }^{(39)}$

The Peruvian government implemented social aid programs aimed at poor populations to help them face the stay-at-home order; this aid consisted mainly of direct payment of 760 Peruvian soles (208.5 US\$), early withdrawal from the private retirement pension, and food donations. In our study, we found that most respondents reported not having been part of this beneficiary population. For example, only $15.7 \%$ received some type of support from the government and of these only $25.6 \%$ was allocated to people with pre-pandemic monthly income below the minimum living wage (less than 255 US\$) and 55.6\% to people with monthly income from 256 to766 US\$ (data not shown in tables). We do not have information on the percentage of the vulnerable population that did not receive government aid to face the stay-at-home order in Peru. However, it has been reported that the data source used to identify vulnerable households was designed for regular contexts and does not allow for the identification of families that abruptly entered poverty due to the mandatory stay-at-home order. ${ }^{(5)}$ Problems with receiving money from social assistance were also reported, because nearly 14 million adult Peruvians (59.8\% of the total adult population) did not have a bank account. ${ }^{(40)}$ For this reason, our results invite further analysis and discussion on the targeting and delivery of government social aid to vulnerable populations during the pandemic.

On the other hand, the high food price perception during the pandemic (55.6\% participants reported an increase in the price of processed food in our study) may have limited the capacity to buy or access food during the pandemic. Loss of jobs ${ }^{(11,41)}$ and increase in food prices ${ }^{(12)}$ are some of the side effects of stay-at-home orders reported by other studies.

In this study we found that people who had reported consuming less minimally processed food were more likely to experience MSFI, this may be due to reduced access to food in terms of quantity and quality, increased food price or having some fear of SARS-CoV2 infection in markets because products are not packaged. ${ }^{(42)}$

It is possible that one of the reasons heads of households were more likely to suffer from MSFI could be stress and anxiety related to getting food and having to prioritize feeding their family over themselves. ${ }^{(7)}$ This result could be related to the perception of losing weight that, in our study, was associated with MSFI.

Our findings demonstrate a greater chance of experiencing MSFI in participants with relatives who were probable cases of SARS-CoV2. Even though there is no evidence about a direct relationship between MSFI and SARS-CoV2, we suggest that there could be an indirect relationship, as household economic resources could be allocated primarily to treatment or care of the infected household member instead of providing food at home.

The study has some limitations. Because it is a cross-sectional study; it cannot establish causal relationships. There might be bias as participants were not randomly selected, thus the results shown are only generalizable to our study population. 
medRxiv preprint doi: https://doi.org/10.1101/2021.02.06.21251221; this version posted March 31, 2021. The copyright holder for this

preprint (which was not certified by peer review) is the author/funder, who has granted medRxiv a license to display the preprint in

It is made available under a CC-BY-NC-ND 4.0 International license .

It is important to discuss how the sample was obtained. This study employed a web-based survey where participants were not randomly selected. Ideally, we expected to have a sample with sociodemographic characteristics similar to the Peruvian national population $(21.2 \%$ and $20 \cdot 8 \%$ within the poorest and poor quintiles, respectively; $28.8 \%$ residing in the province of Metropolitan Lima; $60 \%$ of women between 15-49 years old having at least secondary education and around $40 \%$ having higher education). ${ }^{(43,44)}$ However, our sample consisted mainly of women (74.9\%) and people who residing in the province of Metropolitan Lima (67.7\%); with only $12.9 \%$ of those women have at least secondary level education, $87.1 \%$ have higher or university education (data not shown) and with $12.4 \%$ of households reporting an average monthly income of less than 255 US\$/month in pre-pandemic period (similar to the poorest quintile of the Peruvian national population). Considering these discrepancies between the general Peruvian population and our study sample, we can mention that this study's sample has a similar distribution to Peruvian population that live in Metropolitan Lima, with an upper-middle income socioeconomic status and it is not generalizable to the whole Peru. However, we showed important evidence on MSFI in the context of the stay-at-home order due to the COVID-19 pandemic in Peru.

In conclusion, people who went through MSFI were economically vulnerable both before and during stay-at-home order due to COVID-19 pandemic in Peru. Factors most strongly associated with MSFI included being a head of household, consuming less minimally processed food, and perceiving losing weight. It is necessary to implement effective social assistance policies to prevent or mitigate these adverse effects. 
medRxiv preprint doi: https://doi.org/10.1101/2021.02.06.21251221; this version posted March 31, 2021. The copyright holder for this preprint (which was not certified by peer review) is the author/funder, who has granted medRxiv a license to display the preprint in

It is made available under a CC-BY-NC-ND 4.0 International license .

\section{REFERENCES}

1. Ensheng Dong HD, Lauren Gardner. An interactive web-based dashboard to track COVID-19 in real time. The Lancet. 2020;20:533-4.

2. MINSA. Sala situacional COVID-19 Perú: Ministerio de Salud

2020 [Available from: https://covid19.minsa.gob.pe/sala situacional.asp.

3. Worldometer. COVID-19 Coronavirus Pandemic. Reported Cases and Deaths by Country, Territory, or Conveyance 2020 [Available from: https://www.worldometers.info/coronavirus/?utm campaign=homeAdvegas1?

4. Sohrabi C AZ, O'Neill N, et al. World Health Organization declares global emergency: A review of the 2019 novel coronavirus (COVID-19) Int J Surg. 2020;2020(76):71-6.

5. Jaramillo M N $\mathrm{N}$. COVID-19 y shock externo Impactos económicos y opciones de política en el Perú. Serie de documentos de política pública

PNUD América Latina y el Caribe 2020.

6. GRADE. The COVID-19 Pandemic and Food Insecurity in Peru, by Eduardo Zegarra: Group for the Analysis of Depelopment 2020 [Available from: https://www.grade.org.pe/en/novedades/the-covid-19-pandemic-and-food-insecurityin-peru-by-eduardo-zegarra/.

7. Anna L SW, Kartika P, Hilary S. A conceptual model for understanding the rapid COVID-19-related increase in food insecurity and its impact on health and healthcare. Am J Clin Nutr. 2020;00(1-8).

8. Lives Y. Listening to Young Lives at Work in Peru: First Call. 2020 Agosto 2020.: GRADE, IIN; 2020 [updated Agosto 2020. Available from: https://www.younglives.org.uk/content/listening-young-lives-work-peru-first-call.

9. INEI. Nota de prensa INEI: Empleo en Lima Metropolitana disminuyó en 2 millones 318 mil 300 personas durante el trimestre marzo-abril-mayo del presente año

2020 [updated 15/06/2020 Available from: https://www.inei.gob.pe/prensa/noticias/empleo-en-lima-metropolitana-disminuyoen-2-millones-318-mil-300-personas-durante-el-trimestre-marzo-abril-mayo-delpresente-ano-12253/.

10. Parker Kim MJ, Brown Anna. About Half of Lower-Income Americans Report Household Job or Wage Loss Due to COVID-19 2020 [Available from: https://www.pewsocialtrends.org/2020/04/21/about-half-of-lower-income-americansreport-household-job-or-wage-loss-due-to-covid-19/.

11. Hamadani JD HM, Baldi AJ, et al. Immediate impact of stay-at-home orders to control COVID-19 transmission on socioeconomic conditions, food insecurity, mental health, and intimate partner violence in Bangladeshi women and their families: an interrupted time series. Lancet Glob Health. 2020;S2214-109X(20):30366-1.

12. Akter S. The impact of COVID-19 related 'stay-at-home' restrictions on food prices in Europe: findings from a preliminary analysis. Food Secur. 2020:1-7.

13. Bracale R VC. Changes in food choice following restrictive measures due to Covid19. Nutr Metab Cardiovasc Dis. 2020;30(9):1423-6.

14. Niles MT, Bertmann F, Belarmino EH, Wentworth T, Biehl E, Neff RA. The Early Food Insecurity Impacts of COVID-19. Nutrients. 2020;12(7):2096.

15. Kansiime MK, Tambo JA, Mugambi I, Bundi M, Kara A, Owuor C. COVID-19 implications on household income and food security in Kenya and Uganda: Findings from a rapid assessment. World development. 2021;137:105199-.

16. Dondi A, Candela E, Morigi F, Lenzi J, Pierantoni L, Lanari M. Parents' Perception of Food Insecurity and of Its Effects on Their Children in Italy Six Months after the COVID-19 Pandemic Outbreak. Nutrients. 2021;13(1):121.

17. IFPRI. 2020 Global report on food crises. Joint analysis for better decisions 2020 [Available from: https://www.ifpri.org/publication/2020-global-report-food-crises-jointanalysis-better-decisions. 
medRxiv preprint doi: https://doi.org/10.1101/2021.02.06.21251221; this version posted March 31, 2021. The copyright holder for this preprint (which was not certified by peer review) is the author/funder, who has granted medRxiv a license to display the preprint in

It is made available under a CC-BY-NC-ND 4.0 International license .

18. FAO I, UNICEF, WFP, WHO. The State of Food Security and Nutrition in the World 2020. Transforming food systems for affordable healthy diets Rome2020 [Available from: https://doi.org/10.4060/ca9692en.

19. FAO. Methods for estimating comparable prevalence rates of food insecurity experienced by adults throughout the world Rome: FAO; 2016 [Available from: http://www.fao.org/3/a-i4830e.pdf.

20. Ballard TJ KA, Cafiero C, Schmidhuber J. Better measurement of food insecurity in the context of enhancing nutrition. Ernahrungs Umschau. 2014;61(2):38-41.

21. Carlo Cafiero SV, Mark Nord. Food security measurement in a global context: The food insecurity experience. 2018;116:146-52.

22. Smith MD, Rabbitt MP, Coleman- Jensen A. Who are the World's Food Insecure? New Evidence from the Food and Agriculture Organization's Food Insecurity Experience Scale. World Development. 2017;93:402-12.

23. Sinclair K, Ahmadigheidari D, Dallmann D, Miller M, Melgar-Quiñonez H. Rural women: Most likely to experience food insecurity and poor health in low- and middleincome countries. Global Food Security. 2019;23:104-15.

24. Frongillo $\mathrm{E} \mathrm{NH}$, Smith M, Coleman-Jensen A. Food Insecurity Is More Strongly Associated with Poor Subjective Well-Being in More-Developed Countries than in Less-Developed Countries. The Journal of Nutrition. 2018;149(2):330-5.

25. Grimaccia E NA. Food Insecurity Individual Experience: A Comparison of Economic and Social Characteristics of the Most Vulnerable Groups in the World. Social Indicators Research. 2019;143(1):391-410.

26. Wambogo EA, Ghattas H, Leonard KL, Sahyoun NR. Validity of the Food Insecurity Experience Scale for Use in Sub-Saharan Africa and Characteristics of Food-Insecure Individuals. Current Developments in Nutrition. 2018;2(9).

27. Karpyn A HG, Knowles Z. Validity of the Food Insecurity Experience Scale and Prevalence of Food Insecurity in the Bahamas. 2020.

28. Asfahani Fea. Food Insecurity and Subjective Wellbeing Among Arab Youth Living in Varying Contexts of Political Instability. Journal of Adolescent Health. 2018; 64.

29. Vargas S PM. Measuring food insecurity and hunger in Peru: A qualitative and quantitative analysis of an adapted version of the USDA's Food Insecurity and Hunger Module. . Public Health Nutrition. 2010;13(10):1488-97.

30. Ballard TJ, Kepple, A.W. \& Cafiero, C. The food insecurity experience scale: development of a global standard for monitoring hunger worldwide. Technical Paper Rome: $\quad$ FAO; 2013 [Available from: http://www.fao.org/fileadmin/templates/ess/voh/FIES Technical Paper v1.1.pdf.

31. Gaitán-Rossi P, Vilar-Compte M, Teruel G, Pérez-Escamilla R. Food insecurity measurement and prevalence estimates during the COVID-19 pandemic in a repeated cross-sectional survey in Mexico. Public health nutrition. 2021;24(3):412-21.

32. Depa J GF, Muller A, Eleraky L, Hilzendegen C, Stroebele-Benschop N. Prevalence of food insecurity among food bank users in Germany and its association with population characteristics. Preventive medicine reports. 2018;9:96-101.

33. Stunkard AJ, Sørensen T, Schulsinger F. Use of the Danish Adoption Register for the study of obesity and thinness. Research publications - Association for Research in Nervous and Mental Disease. 1983;60:115-20.

34. RM.weights: Weighted Rasch Modeling and Extensions using Conditional Maximum Likelihood [Internet]. 2018. Available from: https://cran.rproject.org/web/packages/RM.weights/index.html.

35. FAO F, OMS, PMA, UNICEF. El estado de la seguridad alimentaria y la nutrición en el mundo 2019. Protegerse frente a la desaceleración y el debilitamiento de la economía Roma: FAO; 2019 [

36. Elsahoryi N, Al-Sayyed H, Odeh M, McGrattan A, Hammad F. Effect of Covid-19 on food security: A cross-sectional survey. Clin Nutr ESPEN. 2020;40:171-8. 
medRxiv preprint doi: https://doi.org/10.1101/2021.02.06.21251221; this version posted March 31, 2021. The copyright holder for this preprint (which was not certified by peer review) is the author/funder, who has granted medRxiv a license to display the preprint in It is made available under a CC-BY-NC-ND 4.0 International license .

37. Manfrinato CV, Marino A, Condé VF, Franco MdCP, Stedefeldt E, Tomita LY. High prevalence of food insecurity, the adverse impact of COVID-19 in Brazilian favela. Public Health Nutrition. 2020:1-14.

38. Owens MR, Brito-Silva F, Kirkland T, Moore CE, Davis KE, Patterson MA, et al. Prevalence and Social Determinants of Food Insecurity among College Students during the COVID-19 Pandemic. Nutrients. 2020;12(9).

39. Kent K, Murray S, Penrose B, Auckland S, Visentin D, Godrich S, et al. Prevalence and Socio-Demographic Predictors of Food Insecurity in Australia during the COVID19 Pandemic. Nutrients. 2020;12(9).

40. Peruano E. MEF: Todos los peruanos tendrán una cuenta bancaria al 28 de julio del 2021 Lima2020 [Available from: https://elperuano.pe/noticia/102330-mef-todos-losperuanos-tendran-una-cuenta-bancaria-al-28-de-julio-del-2021.

41. Ahmed F IA, Pakrashi D, Rahman T, Abu S. Determinants and Dynamics of Food Insecurity During COVID-19 2020 [updated September 2. Available from: http://users.monash.edu/ asaduli/pub/foodsec-covid.pdf.

42. Scarmozzino F VF. Covid-19 and the Subsequent Lockdown Modified Dietary Habits of Almost Half the Population in an Italian Sample. Foods. 2020;9(5):675.

43. INEI. National Institute of Statistics and Informatic. Demographic and Family Health Survey (DHS)

2019 [Available from: https://proyectos.inei.gob.pe/endes/.

44. National Institute of Statistics and Informatics. Peru: Population Projections, by Department, Province and District, 2018-2020". 2020 [Available from: https://www.inei.gob.pe/media/MenuRecursivo/publicaciones digitales/Est/Lib1715/

\section{AUTHORSHIP CONTRIBUTIONS}

$\mathrm{OCH}, \mathrm{MP}$ and JLC led the design of the study. JLC, OCH, SH, GD, AA, and JPG contributed to designing and validating the instrument and collecting of data. JLC and OAE carried out the data analysis. DAA, JPA and MP were responsible for the interpretation of the results. JLC contributed to the initial drafting of the manuscript based on comments from DAA, MP, and JPA. All authors contributed to the interpretation of data, critical revision of the manuscript and approved the final version.

\section{DECLARATION OF INTERESTS}

We declare no competing interests.

\section{DATA SHARING}

Requests of survey data will be considered for research purposes, while does not conflict with other requests by the study authors. Requests should be made to Jorge L. Cañari-Casaño (jorge.canari@outlook.com).

\section{ACKNOWLEDGMENTS}

We want to thank Rikolto in Latin America and the Belgian cooperation for their contribution in designing the advertising campaign on social media. We also thank Colegio de Nutricionistas del Perú, Universidad Nacional Mayor de San Marcos and all the public Peruvians universities that sharing at not cost our survey online from their official social media pages.

JLC is a doctoral student studying an Epidemiological Research Doctorate at Universidad Peruana Cayetano Heredia under FONDECYT/CIENCIACTIVA scholarship EF033-235-2015 and supported by training grant D43 TW007393 awarded by the Fogarty International Center of the US National Institutes of Health. 
medRxiv preprint doi: https://doi.org/10.1101/2021.02.06.21251221; this version posted March 31, 2021. The copyright holder for this preprint (which was not certified by peer review) is the author/funder, who has granted medRxiv a license to display the preprint in It is made available under a CC-BY-NC-ND 4.0 International license .

We also express our acknowledgement to Hilary Creed for her comments on our protocol of study and John Nesemann, for his review of the English version of our manuscript.

\section{CORRESPONDENT AUTHOR}

Jorge Luis Cañari Casaño

Email: jorge.canari@outlook.com 